Instituto de Estudios Sociales Avanzados (CSIC) Working Paper 92-09

\title{
Technology Policy in Spain: Issues, Concerns and Problems
}

Luis Sanz-Menéndez and Emilio Muñoz

Consejo Superior de Investigaciones Científicas (CSIC) 


\title{
Technology Policy in Spain: Issues, Concerns and Problems
}

\author{
Luis Sanz-Menendez and Emilio Muñoz
}

\section{Introduction}

The relation between science and technology is becoming narrower every day and their development has implications for economy and consequently, society, influencing the quality of life and working conditions of citizens.

The levels of economic and scientific/technological development appear to be strongly associated, at least over the last thirty years. Several empirical studies (Pavitt 1979, 1980; Soete 1981; Fagerberg 1987; Quintanilla 1992) have identified the indicators of economic or scientific and technological development which have a tendency to vary most significantly, according to countries and periods.

The dominant conception of scientific and technological relations with economy has been characterized, in recent decades, by a linear model (e.g. Salter 1960). Some works, influenced by organization theory, began to develop alternative approaches, such as the evolutionary models of technological change (Nelson et al. 1976; Nelson/Winter 1977; Nelson/Winter 1982; Dosi 1988, 1991). The elimination of automatism from the linear model has helped to concentrate attention on a single serious issue, the global functioning of the science-technology-industry system.

More recent research (e.g. Mowery/Rosenberg 1989; Rosenberg 1991) has emphasized the importance of considering the efficiency of the scientific/technological system as a whole, and not in its particular elements, such as the scientific, technological or commercial aspects. The system is a mechanism which incorporates inputs and outputs, it is predisposed to its own transformation, a machine whose internal configuration and organization can assure a variety of functions. The contribution of science and technology to the development and competitiveness of economies appears to be marked by institutional and organizational factors which ought not to be ignored.

Certain studies of an historical character have contributed to the identification of the decisive processes which helped to develop and configurate the institutions in different countries which can be included in the so-called science-technologyindustry system. Most of these works, however, refer to the United States (e.g. Noble 1977). 
In the case of the development of R\&D activities and of specific organizations, from the commercial perspective, the progression of organizational transformations in corporations appears to have played a major part in the development of organized capitalism. In fact, the evolution of industrial organization and the appearance of planning or programming units contributed to the establishment of a space for the institutionalization of innovative activities in businesses (Noble 1977; Chandler 1962, 1977). On the other hand, as it has been suggested (Schumpeter 1939), the seed of many businesses in new sectors of production can be found in the early processes of technological innovation.

Public intervention and concern of an explicit nature, seem to be derived from the programs for scientific/military development of the inter-war years (Ronayne 1984). The history of the scientific/technological effort in conjunction with the first steps taken in developing its results are associated with the development of the scientific/technological potential related to war.

In science and technology, as in economic development, every country is a product of its history, of its past, of its degree of economic development, and of its state policies, often closely associated with external military concerns. In this way, the situation of the science-technology-industry system appears to be associated, in a decisive way, with the attained levels of economic development.

However, to explain the development of public policies, analysts have fallen into two major currents: on the one hand, those who based their views on prerequisites, and argued that the causes of the development of scientific and technological policies are generally associated with the degree of economic and social modernization; and on the other hand, those who maintain the diffusion thesis, who concentrate on the study of the imitation of scientific policy programs between countries, or of their diffusion via organisms of a multinational character (like UNESCO or OECD).

The situation in Spain in the mid-1970s, during the democratic transition, where scientific and technological issues are concerned, was far removed from the rest of Europe. Undoubtedly, the scientific/technological vacuum in Spain was much greater than the economic one (Sanz/García 1990). Spain spent a mere 0.3\% of its GDP in the mid-1970s and early 1980s on the development of R\&D activities, one of the lowest percentages amongst the developed countries (OECD 1971).

The early years of the transition helped to freeze the situation, within an international context of a general stagnation of R\&D (Gerelli 1983). National priorities were concentrated on political reform and the development of social compensations aimed towards the organization of the welfare state. The absence of science and technology in the Pactos de la Moncloa is very significant.

It was not until the electoral victory of the Socialist party, which renewed the political leadership of the country, that the importance of science and technology grew, together with a corresponding public interest.

The diagnosis which was made, after the establishment of the first socialist Cabinet, was very clear (Muñoz/Ornia 1986). The Spanish scientific/technological 
system was characterized by: (i) a small size and very little research; (ii) the large size of the public sector (universities and public research centers), to the detriment of business; (iii) a heavy imbalance of human resources against engineering and technology; (iv) a lack of cooperation between the directors and agents of R\&D programs; ( $v$ ) serious regional imbalances in scientific/technological material resources; and (vi) an absence of public policy coordination.

After a number of years of efforts of a budgetary, organizational and incentiveproducing nature, the situation of the science-technology-industry system in Spain appears to have evolved favorably, although in 1992, Spain still spends less than $1 \%$ of its GDP on scientific and technological projects. A recent study (Quintanilla 1992) has indicated that Spain has, amongst all other EC countries, experienced the greatest and most sustained growth in $R \& D$ projects in the final years of the decade of the 1980s. However, in spite of this it is still well below the community average and the leading country, Germany. In the field of public policy in science and technology there have also been some developments; among others, the growth of public spending, the creation of instruments of intervention like the National Research and Development Plan, and the fixing of priority research areas.

Nevertheless, historical inertia in the working of the science-technologyindustry system, the effects of policies, and the process of accelerated change have brought about situations of concern within this improved context. There is still a general deficit of engineers and technologists, financial investment is very low, the proportional contribution of personnel by universities for R\&D continues to be very high, and the covering of technological imports is very low.

Social and ecological concerns in Spain are underdeveloped, against that which could be expected, given the magnitude of these problems. There is a high degree of unemployment, growing desertification, and evident problems with respect to biodiversity, but there is a lack of awareness in public opinion and in the key role of government determination of political agendas on these matters. The Spanish political scene has a low incidence of interest group pressure. Thus, the priorities of Spanish scientific and technological policy have been characterized by this underdevelopment, by the need to prioritize the growth of the scientific/technological system, and by the creation of hitherto unselective policies.

In the present analysis, the aim is to examine history and policy, and to explore the way in which political processes, in the context of the Spanish democratic transition and consolidation, have helped to create science and technology programs and policies. The introduction of science and technology initiatives on the political agenda is often the result of the action of organized social and economic interest. But the sensibility of public opinion is also an element of great importance in explaining the hierarchy of priorities in public action. The state and governments are also organizations and sources for the development of autonomous initiatives. It is therefore the case that their institutional structures can affect the political process decisively, and contribute to the emergence or consolidation of a certain 
type of public policy, in this case, science policy. On the other hand, science and technology policy transforms social and political reality.

We aim to describe the basic characteristics of the Spanish science-technologyindustry system and to explore the most significant science and technology policy proposals which have been considered in the last ten years. This study therefore operates in two streams of analysis: the reality of the science-technology-industry system in Spain and the actions of public policy in relation to this system.

The conclusion one might draw from the present study is that, in this context, science policy initiatives respond to the processes of the diffusion of policies and knowledge from international sources, and not from specific interests or bureaucratic action. This is the case in spite of the fact that the establishment of science and technology policies after the socialist election victory in 1982 was characterized by a strong political and administrative leadership.

The fixing of ecological and social objectives is rather meagre, and in any case, very recent. International pressure (from the EC) on government action appears to have been decisive, given that the awareness in Spanish public opinion on these questions is still very low.

\section{Antecedents of the Spanish Situation in Science and Technology: 1940-1975}

The present situation of science and technology in Spain is to a large degree a result of its most recent past. The country's economic configuration after the Civil War (1936-1939), the political alignment of the Francoist dictatorship with the fascist powers during World War II and the exclusion of Spain in the reconstruction of Europe (the Marshall Plan), were to have decisive consequences for science and technology and the type of policy, or absence of policy, adopted by the Spanish state.

\subsection{From Self-sufficiency to the Stabilization Plan: 1939-1959}

The economic effects of the Civil War, but in particular the situation of political isolation the Francoist dictatorship found itself in after the end of the Second World War, resulted in a reconstruction policy based on autarquía, or selfsufficiency (see Ros-Hombravella 1973; Carreras 1987; García-Delgado 1987). This economic policy strategy (interventionism and isolation) and its accompanying circumstances did not ensure pre-war production levels until well into the 1950s; the most recent historiography talks of the "costs" of this period for the Spanish economy (Carreras 1987). 
Concretely, the self-sufficient model required the application of many of the working methods of economic intervention by the state used during the war: administrative freezing of prices, narrow control over private investment, the creation of national interest industries, direct state investment via the National Institute for Industry (INI), the centralization of the provision of raw materials and of importation permits, and so on. This was all in addition to labor and commercial relations determined by a rigid, authoritarian and paternalistic model. This selfsufficient and interventionist strategy was also a response to the ideological and doctrinal position of the winning forces of the Civil War. At the same time, the protectionist attitude was also a continuation of policies which have characterized Spain since the end of the nineteenth century (Espina 1992).

The two first decades of the Franco regime were characterized by the move towards the industrialization of the country, a process which was considered to have failed and which was awaiting success. The documents of the time testify to the main objective: to increase production. ${ }^{1}$ State fiscal policy was put at the service of industrialization.

There was a general conviction that the country was backward, as a result of an unfortunate economic administration; it was supposed that the state was the only agent capable of breaking away from the preceding situation, and for this reason the INI was created on September 25th, 1941. Four essential postulates ought to be noted (Martín-Aceña/Comín 1992:429-430): (i) the need to establish an industrialization effort which would ensure the economic take-off of the country and the launching of a powerful economy; (ii) the recognition of the inability of private initiatives to take on investment responsibility and to make up for the endemic lack of enterprise; (iii) the association between industrialization and national defence; and (iv) the acceptance that there were no appropriate credit systems to finance programs which would promote these objectives.

In the hope of attaining its objectives, the INI designed a program of action which covered a varied group of industrial sectors: solid and liquid fuels, iron, steel and aluminium, fertilizers, cellulose and artificial fibers, engines, industrial vehicles and automobiles, machines and tools, electrical goods, naval construction, and the production of electrical energy. Within this ambitious program, the reality of the results would expose the specialization of the Spanish economy around the primary sector and raw materials, and an orientation, in order to promote industrialization and the substitution of imported goods, towards difficult and unattractive sectors for private enterprise (Myro 1981).

All of these circumstances coincided with the European post-war years and with the attempts brought about by President Roosevelt in the United States (Bush 1945) to engineer the first 'non-military' actions in science and technology policy, and which would eventually be picked up and channeled by different states and international organisms such as UNESCO and OECD.

In Spain, at that time, there was no explicit science and technology policy but, as Nieto (1990) points out, the key to scientific action, from 1939 onwards, was 
held by the Higher Council for Scientific Research (CSIC). At the same time as the industrialization process adopted by the regime, the government of the day was able to see the need for research in a modern society, and created the CSIC by legislation on November 24th, $1939^{2}$, later modified by another law on July 22nd, 1942. It states that the fundamental organ of support for scientific research is the state, and consequently, the coordination of all activities and institutions engaged in science is its responsibility. Thus the purpose of the CSIC was to encourage, orientate and coordinate scientific research in Spain. The idea was very ambitious, given that in the organization's statutes it was required to coordinate all of Spain's research centers, the relation between research and the economy and the possibility of territorial expansion.

It is the case that for certain reasons (Muñoz/Ornia 1986:38, 49; Nieto 1990:3133; Muñoz 1990:18-19) this institution, a potential instrument of scientific policy, which was also attempting to connect with industrial and technological development, did not become functionally operative. This failure lies in the conflicting views of the CSIC's creators and in the passive attitude of those which opted for this model.

The universities, for their part, had suffered severe losses as a result of the Civil War, and in the context of a general absence of a research infrastructure, they were hardly in a position to promote scientific activity. On the other hand, they have experienced a complex relationship with the CSIC which has not provided very satisfactory results (Lora Tamayo 1990).

\subsection{The Period of "Developmentism" in Spain: 1960-1975}

At the end of the decade of the 1950s, there was a change in Spanish economic policy. After the end of political isolation (Spanish-American Pacts, 1953), the Franco regime changed its strategy - in 1959, it presented the Stabilization Plan to the International Monetary Fund. There was an opening up to the exterior, tourism was promoted and industrial development was sought by means of applying foreign technology for domestic use, attempting to make the best use of the country's cheap but underqualified labor force. The protectionist measures which characterize Spain's recent history remained unaltered.

This period in Spanish history, which covers the beginning of the 1960s until the oil crisis, yielded positive results, increasing production and placing Spain amongst the industrialized countries.

In spite of the notable advances in Spanish economic development, the scientific and technological situation remained far behind. In 1963, the R\&D expenditure did not reach $0.2 \%$ of the GDP. The situation, in the years 1967-1975, did not vary substantially, given that Spanish R\&D hovered around $0.3 \%$ of the GDP. This was one of the lowest percentages of the developed countries, be they free market economies or planned economies (OECD 1971). In this context, it can be 
said that science policy did not improve at all and continued in this way. Spain lacked a science policy (Nieto 1982; Muñoz 1982), although there clearly was a will to increase state support for scientific and technological research.

In this period, development plans were launched as a means to guide and generate economic inertia. These plans included $R \& D$ in their guidelines, as a response, among other things, to the OECD reports. In one of these, published in 1971 , it was recommended by the international organism that "Spain should spend $0.5 \%$ of its GDP on R\&D with no further delay" (OECD 1971:67), underlining that this was feasible with little effort. The development plans had considered substantial increases of resources for R\&D, to try to reach $1 \%$ of the GDP by the 3rd Plan (1972-1975). However, the difference between the resources requested for scientific research and those eventually conceded was significant. ${ }^{3}$ The fundamental problem was that Spain lacked a modern domestic fiscal policy. This is reflected in the fact that the first fiscal law was only introduced during the democratic transition.

In any case, it is worth reminding ourselves that the 1st Development Plan (1964-1967) had as its fundamental objective, within the field of $R \& D$, to develop the scientific infrastructure. The National Fund for the Development of Scientific Research was created, run by the Commission for the Assessment of Scientific and Technological Research (CAICYT), founded in 1958 and boosted in 1963 with the aim of taking up the tasks the CSIC had been unable to put into practice, and to thus compensate for the deficiencies in science policy. The 2nd Development Plan (1968-1971) tried to improve the personnel and installation infrastructure, as well as supporting research in industry via the concerted research plans - a mechanism in which the state participated financially in the R\&D projects of businesses paying up to half its costs - and the funding of official research via a grant system for projects. The 3rd Development Plan changed the course of action by aiming towards technological development and concentrating its focus on given projects in various sectors.

However, these plans of action aiming to lay the foundations for a science and technology policy and to increase the funding of R\&D in Spain were suspended in 1976. The 4th Development Plan, prepared for the period 1976-1979, went into crisis and eventually collapsed. The provisions which were laid out in the 4th Plan for investment in R\&D were not specifically included in the annual budgetary laws. This situation put Spanish scientific and technological research on the brink of chaos, shortly after having achieved the minimal conditions for growth.

This crisis in Spanish science policy coincided with the reduction in R\&D in the international context of the developed countries, after the oil crisis. This kind of delay is a feature which seems to appear regularly in the history of R\&D funding in Spain, on a comparative level with the advanced nations, to the point of becoming a constant. On the other hand, science and technology in Spain are invariably victims rather than motors of economic policv. This is a condition which prevents 
prioritization to ensure a smooth growth rather than progress which is subject to unpredictable decision-making.

In any case, in those years, most of the work carried out as a result of science policies was taken up by research centers (among which, as well as the CSIC, the Nuclear Energy Group [JEN] was very important), although during the 1960-1975 period the Spanish administration put various mechanisms into practice to stimulate the development of research in industry. One of these formed a part of the concerted plans, mentioned above, which was a system used in various European countries, aiming to promote research in business. It also hoped, at the same time, to be of general benefit and to create a research infrastructure in private industry. In the course of this action, it was also hoped that some contact between business and public research centers would be stimulated, generating a possible collaboration between both elements of the science/technology system. The formula undoubtedly contributed to the promotion of R\&D initiatives in businesses, but the collaboration between businesses and research centers did not yield very good results, given that it tended to favor contacts based on subcontracting services. On the other had, businesses complained of a certain slowness in the bureaucratic procedure, which first examined applications, then made a selection, then proceeded with funding. In short, the difficulties of accommodating administrative functioning to business activity became evident.

Another measure, analogous with the experience of other countries, as in Germany with the Fraunhofer Society, was the creation of the research associations in 1961. The main aim of these associations was the development of programs of common interest for the businesses of a particular sector. The results of these initiatives could benefit any of the businesses involved which contributed to the development of so-called cooperative research. From 1962 until 1980, up to 29 of these were created, the majority (16-18) of which ran reasonably well. The formula was improved in 1970 to ensure the best possible use of human resources, scientific and technical personnel available.

It is significant that these initiatives, managed via CAICYT, were ultimately administered by the Ministry of Education and Science. The Ministry of Industry had stood aside from technological promotion, perhaps excepting the development of nuclear energy via the JEN, the importance of which we remarked above. In any case, the precarious position of science and technology in Spain was well reflected in the figures for the technological deficit, together with the meagre support given to $R \& D$ by the business sector. ${ }^{4}$ 


\section{The Position of Science and Technology during the Democratic Transition}

It is evident from the above that in the mid-1970s, at the beginning of the democratic transition ${ }^{5}$, the legacy of the dictatorship was a very negative one. The following factors determined the parameters of science and technology in Spain during this period:

1. The historical narrowness of an industrial system designed for selfsufficiency during the 1940s and 1950s, which was too closed and not at all competitive on the international markets. This provided a very weak structure for Spanish businesses, whose competitive capacity on the domestic market was determined by tax protection. Foreign markets were only sold agricultural produce or products that had been transformed via the cheap labor available. This inferior competitive capacity, combined with the specialization in Spanish industry in branches of intensive capital (Segura 1983), using more equipment than producing more technology (as Pavitt 1984 points out), has been a decisive factor in the tiny investment in R\&D by Spanish enterprise.

2. The development model adopted after the Stabilization Plan was based on the investment of foreign capital in Spain to compete on the domestic market by creating production centers in Spain. From the technological point of view, it ought to be noted that at this stage the massive importation of technological goods began (Sánchez 1984; Buesa/Molero 1989), but without the construction of a national scientific/technological base. This only contributed to the increase of the technological balance of payments deficit.

3. The scientific/technological system was thus very deficient, and research was predominantly concentrated in public centers. The situation of the universities, in the middle of an expansion process but without resources, was marginal, and only some public research centers played a significant role. The devastating effect of the war on the academic system and the conversion of the universities into centers of learning rather than original work, contributed to a major brain drain. It was not until 1960 that the best scientists began to study abroad, but R\&D was still seriously marginalized and fragmented. This was the result of the dispersion of those rivalries created by the Franco regime.

4. From these years onwards, the only priority in science and technology policy was to increase resources for $R \& D$, in such a way that the actions which were carried out were not very selective in their aims. The only objective was to increase the miniscule funding of R\&D in Spain.

5. The few initiatives which were taken to support, rationalize and integrate public action in R\&D came from the Ministry of Education and Science, via CAICYT. The Ministry of Industry was practically absent, and in any case tended to approach problems from the sectorial point of view, as we have pointed out. 
This was the historical position at the end of the dictatorship. Added to the problems of instability during the democratic transition, are the developments of the world economic crisis, as well as the recession in the evolution of R\&D expenditure which began in the mid-1960s (Gerelli 1982).

The official development plans which had been made at the end of the 1960s were suspended given the social pressure to give priority to the task of consolidating the democratic process. The complete absence of a reference to science and technology in the Pactos de la Moncloa is significant. This was an important agreement between the Spanish political parties which served as a basis for the democratic transition.

On the other hand, to the absence of political priorities for science and technology, the grave problems of the universities and businesses must be added. The shock to the system brought about a major industrial crisis which, in conjunction with an inability of businesses to be innovative, underwent a reconversion, and both production and employment dropped. The task of industrial reconstruction lasted all the way up to the first socialist legislature. Moreover, since the end of the $1060 \mathrm{~s}$, university expansion and its hyperpoliticization led to a complete paralysis in academic research and activity.

It can be said, with complete certainty, that the combined effect of the economic crisis of the mid-1970s and the Spanish democratic transition left little room for the development of policies and actions for science and technology (García-Delgado 1990), and this contributed to an even greater depression in the Spanish R\&D system.

At this time, only the creation of the Center for the Technological Development of Industry (CDTI), with the support of the World Bank, in 1977, appears to be of any significance. It aimed to compensate for the lack of government action in the technological development of businesses. Furthermore, in 1980, the Ministry of Industry and Energy continued to advance towards the development of technology, establishing an organism for Industrial Innovation and Technology, to replace the one for Industrial Promotion.

The situation which the first socialist government of the transition was faced with, at the end of 1982, left much to be desired:

- the underdevelopment of the science-technology-industry system, characterized by: a very low investment in R\&D in relation to the GDP, both in absolute and in relative terms; and a major imbalance in the execution of $R \& D$ in favor of the public sector;

- a lack of cooperation in R\&D activities among businesses, universities and public research centers;

- a very high technological dependance on other countries, confirmed by a chronic deficit in the relation between payments and income for technology ${ }^{6}$;

- an inability of policies to coordinate scientific research and technological development; 
- very little selectiveness in objectives and priorities for research and funding;

- the predominance of a 'developmentist' focus, and a complete absence of ecological or social criteria in R\&D activities.

\section{Public Policy Actions in Science and Technology}

The change in political responsibilities which occurred in Spain in 1982, propelled by a debate on the necessary modernization of the country, determined the establishment of a process of reform of the science/technology system and the reorganization of public involvement. The question became a priority on the political agenda of the government as a result of the initiatives of people who took up posts in the Ministries of Education and Science and of Industry and Energy. At last it became possible to attempt the application of the recommendations of international bodies, such as the OECD and UNESCO.

Public priorities are normally determined by a process of rationalizing reality, where organized interests, public opinion, or the attitudes of politicians or bureaucrats might play relevant roles.

In the case of Spanish scientific and technological policy, those who began to exercise a rationalized intervention were politicians and senior civil servants of the administration, influenced decisively by international bodies. Their aim was also to deal with major challenges for modernization. Their activities consisted in increasing resources for the science/technology system, to promote efforts in this field from all sides, and to improve public coordination. It was hoped that this would encourage research in universities and businesses, for which the state prepared a program of financial incentives, increasing funding for research in universities and businesses, for which the state prepared a program of financial incentives, increasing funding for research in universities and increasing grants for businesses to promote their $R \& D$. The creation of instruments of public policy was also a feature of this process, as we shall later see.

\subsection{The Reform of the Science/Technology System in Spain in the 1980s}

The reform process began as an initiative of the Ministry of Education and Science, and developed after an evaluation of the features of the science/technology system. The conclusions (Muñoz/Ornia 1986) pointed out that Spain lacked a coherent model of science policy, or more precisely, an adequate coordination between science policy and technology policy with the subsequent economic and social development. All of the attempts carried out until then, to promote scientific and technical research, and then technological development and innovation, had been built around a model of spontaneity, inspired by the British and North Americans, 
and lacking any sense in a country like Spain, which could not then support such activities financially, and which lacked the adequate human and institutional infrastructure for scientific and technological activities.

The difficulties which determined the character of these policies in Spain had the following roots: one was related to the deficient administrative organization of the science/technology system, which required an immediate structural and organizational reform. Others, of a more general character, were derived from the little attention received by scientific research and technological innovation, as well the sectorial distribution of public funding of R\&D in Spain, by the country's economy and enterprise.

\subsection{The Instruments of Reform}

After the process of analysis, reform was channelled two ways: the first was normative, and was embodied in the law of General Support and Coordination of Technological and Scientific Research; the other, of an operative nature, was the National Plan for Scientific Research and Technological Development (National R\&D Plan).

These means aimed to encourage and promote all activities related to scientific research and technological development, from the creation and expansion of the research infrastructure, to the general promotion of knowledge in all disciplines and their concrete application to goods and services. At the same time, they attempted to establish coordination mechanisms between agents involved in the scientific/technological process.

The law, passed in 1986, which takes its name from a specific article of the Spanish Constitution (149.1.15), covered the coordination and support of all R\&D activities. The general coordinating function was guaranteed, in the absence of a specific ministerial department, by an Interministerial Commission of Science and Technology (CICYT), integrated by representatives of ministries with direct responsibilities in scientific research and technological development, but whose importance corresponded, in this order, to the Ministry of Education and Science and to the Ministry of Industry of Energy. In fact, the law was the result of an agreement between both ministries.

The support provided by the National Plan for Scientific Research and Technological Development (National R\&D Plan) which was aimed towards a generalization of the total financial effort of the country in matters of scientific research and technological development, both in terms of current expenditure and in terms of capital, covering the entire group of programs which would be carried out by the public sector as well as by the private sector.

Universities and businesses, together with public research organisms, were the executors of the R\&D programs of the National Plan. This was explicitly pointed out by the law in Article 5: "to support scientific research and the technological 
development of businesses". This reference acquires particular significance in relation to the connection between research and innovation, so necessary to attain an efficient technological policy.

In Spain, as we have noted above, different means of support were developed for industrial growth and innovation (summarized in Figure 1), but their effectiveness was fairly limited.

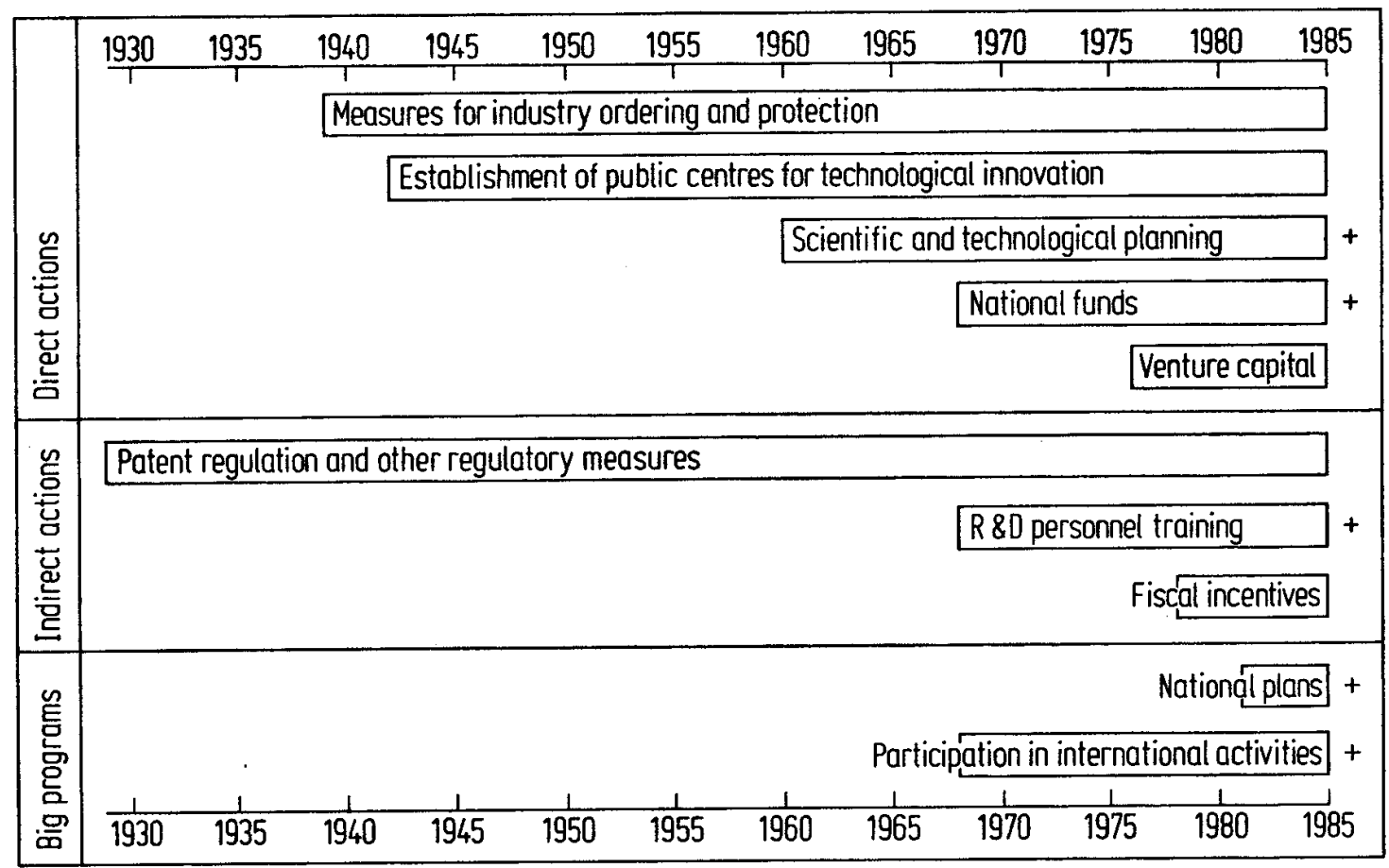

Figure 1: Timetable of steps for promoting technological innovation in Spain before the Science Act 1986

+ Initiatives influenced by the Science Act

[] Periods during which actions have been operative

The National R\&D Plan was established, therefore, as a means to integrate actions of scientific policy and of technological policy, with the collaboration of the most pertinent authorities, the Ministries of Education and Science and of Industry and Energy. However, it must be recognized that there was little selectiveness of the research objectives outlined in this plan. It was conceived as an aggregate of eighteen priority programs, covering almost all the objectives of the European Community guidelines for research programs.

Since it covered all the interests and needs of the science/technology system, within the National Plan, the CDTI acquired particular relevance in its capacity to evaluate the technological and economic interest of projects, as well as promoting the industrial use of technologies, developed by public laboratories, universities 
and research centers, and procuring the technological returns wherever there was Spanish participation in international programs.

\subsection{Technological Policy and the National R\&D Plan}

In 1981, the R\&D expenditure of public and private enterprise reached a level of 35,000 million pesetas ( $25 \%$ of capital and $75 \%$ of current expenditure). In 1983, business expenditure reached 43,000 million pesetas - $0.19 \%$ of the GDP split evenly by the public and the private firms. This activity was characterized by an imbalance in sectorial distribution, given that more than half of the expenditure on $\mathrm{R} \& \mathrm{D}$ was concentrated in three sectors, chemical industries $21.9 \%$, electrical goods and electronic products $18.5 \%$, and transport equipment $15.7 \%$ (Martín/Rodríguez 1985; Saez 1991). Consequently, there was still the effect of the policies of large scale importation of technology, characteristic of the era of "developmentism", as we have noted. This was further aggrieved by the limited capacity for adaptation of imported technology.

For example, in the years 1978-1980, Spanish businesses spent, on average, $0.25 \%$ of their added value on R\&D, while the expenditure on technology was about $0.34 \%$ of the same value (see Table 1 ).

The technology policy included in the scheme of the National R\&D Plan was a generalist policy, of a reactive character and, in many ways, prone to imitation, given that Spanish businesses appeared to act in accordance with a model which clearly depended on the exterior.

The National Plan for Scientific Research and Technological Development, in the period 1988-1991, recognized two fundamental objectives of technology policy, both of which were rather broad: (i) to increase the added value of industrial activities via the incorporation of new technological elements in industrial processes and products ("diffusion"); and (ii) to develop new technological fields in Spain so that the country could offer an adequate scientific and technological potential ("innovation").

This policy admitted the scale of the effort required at that time, while accepting the intrinsic differences between the two objectives, their general nature, and up to a certain point, their spontaneity in that they would require an effort of will. The National Plan, in its early stages, depended for its success upon its becoming an instrument of economic and industrial policy aimed towards modernization and flourishing in Spain. In order for this to be possible, it hoped to accommodate the adaptive capacities of industry to Spain's real potential with the aim of eliminating the bottlenecks which are an obstacle to technological development and to the satisfaction of social demands. As we have pointed out, the National Plan gave the CTDI ample powers to carry out these tasks. 
Technology Policy in Spain: Issues, Concerns and Problems

Table 1: Interindustry comparison between Technological payments (TP) and Business Enterprise Expenditure on R\&D (BERD) in Spain (average from 1978 to 1980), in \%

\begin{tabular}{lrrrr}
\hline Industries & TP & TP/GDP & BERD & BERD/GDP \\
\hline Agriculture & 0.80 & 0.03 & 1.45 & 0.04 \\
Mining and Petrochemical & 1.44 & 0.28 & 4.95 & 0.71 \\
Power, Gas and Water & 6.63 & 0.94 & 2.82 & 0.03 \\
Metal Industries & 3.49 & 0.77 & 6.99 & 1.15 \\
Industry of Non-Metallic & 0.94 & 0.20 & 3.71 & 0.59 \\
Minerals & & & & \\
Chemical Industry & 15.92 & 2.43 & 22.54 & 2.54 \\
Manufacture Metal Goods & 17.56 & & 6.55 & \\
and Machinery & & & & \\
Manufacture Electrical and & 11.73 & 1.88 & 18.18 & 1.17 \\
Electronic Goods & & & & \\
Manufacture Motor Vehicles & 28.41 & 2.80 & 11.70 & 0.85 \\
and Transport Equipment & & & & \\
Food, Drinks and Tobacco & 2.26 & 0.27 & 2.43 & 0.21 \\
Textile Industry & 2.90 & 0.25 & 1.12 & 0.07 \\
Wood and Printing & 0.95 & 0.20 & 0.92 & 0.14 \\
Other Manufacturing Industries & 2.78 & 0.29 & 8.21 & 0.63 \\
Building & 2.66 & 0.11 & 0.38 & 0.01 \\
Service Industries & 1.53 & 0.01 & 8.05 & 0.04 \\
Total & 100.00 & 0.34 & 100.00 & 0.25 \\
\hline & & & & \\
\hline
\end{tabular}

Source: Banco Bilbao: GDP, Instituto Nacional de Estadistica: BERD, Ministerio de Industria y Energía: TP, as cited in Muñoz/Ornia (1986:100)

\subsection{Technology Policy and the Ministry of Industry and Energy}

The elaboration of science and technology policy in the first socialist term had some interesting precedents, with plans of a sectorial character which were launched by the Ministry of Industry and Energy at the end of the 1970s and the beginning of the 1980s.

The most significant precedent, an expression of the interest raised by new technologies, was the National Electronic and Computing Plan (PEIN). In 1981, a committee of exnerts was created for the elahnration of the foundatione of a 
National Plan for Electronics Industry, taking its conclusions to the government in 1983.

Moreover, at the same time as the elaboration of the National R\&D Plan, the Ministry of Industry and Energy defined its own framework of industrial policy, published in 1987, under the title España en Europe: Un futuro industrial (La politica industrial en el horizonte de 1992) (Spain in Europe: an Industrial Future [Industrial Policy Towards 1992]). This work analyzed the situation in Spanish industry, compared it against its European counterparts, and suggested policies and programs designed to attain the aims and objectives in industry in relation to the EC, by 1992. As a result of this action, some of the original programs were continued, such as PEIN, the Plan for Advanced Automatization (PAUTA), as well as the establishment of others, like the Plan for Supporting Research in the Pharmaceutical Industry (FARMA).

Special mention ought to be made, in relation to the social and ecological concerns of R\&D, that in 1989 the Environmental Program for Industry and Technology was approved, to be applied in the period 1990-1994. Its essential objective involves the development of industrial procedures and new technologies which reduce the generation of pollutants. This program runs parallel to the Plan of Technological and Industrial Action (PATI) from 1991 to 1993, which groups together the majority of technology programs of the Ministry of Industry and Energy (PEIN, PAUTA, FARMA, etc.). This plan was initially established as complementary to the National Plan, operating within the private sector. However, early data are beginning to reveal that the National R\&D Plan and PATI are not complementary but competitive. A major distorting element has been introduced with the creation of two units of political and administrative control, attempting the same task without coordination.

\section{Large Policies, Little Ecological and Social Awareness}

Only recently has there been an evaluation of the last ten years of Spanish science and technology policies. Some are simply triumphalist in their appraisal of the recent events (Rojo 1991; Lafuente/Oro 1991; CICYT 1991). Others, in spite of their recognition of the drastic improvement of the situation, still detect grave structural deficiencies or worrying tendencies (Quintanilla 1992; Sanz/Pfretzschner 1992).

These data (see Table 2) show that Spain has been the EC country with the highest rate of growth in recent years. The creation of science and technology policies has contributed to the growth in Spanish participation in European R\&D, representing $4 \%$ of the European total in 1990, compared with the $2.4 \%$ of 1984 . Much of the merit is due to the financial effort of the state and in the increased contribution of businesses. In fact, the participation of private enterprise has 
reached $57 \%$ of the national total, and at the same time, the size of the public financial contribution to private R\&D has risen from $2 \%$ to $16 \%$ in 1990 .

The establishment of these science and technology policies has not helped to defend Spain from some of the difficulties which are approaching with the Single European Market, in particular for industries which will require a high technological level (Martín 1990).

So, as we have pointed out, the existing difference in science and technology between Spain and the rest of the European Community is very significant. It can be expressed in the figure that Spain spends something under $0.9 \%$ of its GDP on $\mathrm{R} \& \mathrm{D}$, while the EC average is over $2 \%$.

But the difference is not only quantitative, it is also qualitative. When the rest of the EC the main concerns centred around new social and ecological approaches, which aimed to incorporate the quality of life into $R \& D$, Spain was still in the middle of the struggle to increase its $R \& D$ effort.

The introduction of concerns of a social and ecological character for the development and practice of $R \& D$ are hardly existent, secondary, and, in any case, very recent, especially when compared to the basic objective when increasing the size and effort of research in Spain. Amongst the primary objectives of R\&D, only recently, around 1988-1989, has the environment begun to occupy a relevant place.

We must remember that the first public plan for scientific research and technological development, the National R\&D Plan, began to operate in 1988. It contained some priority clauses related to aspects of the quality of life and to environmental problems, such as desertification (Crespo et al. 1991:245-246), and some social aspects, such as the labor market, in relation to $R \& D$, but with hardly the appropriate resources to carry them out.

In the plans of the Ministry of Industry and Energy, as we have said, environmental industries have become the targets of technology policy since 1990 (De Andrés 1991).

An analysis of the official statistics for R\&D reveals that during the decade of the 1980s, social and environmental concerns were marginalized within the whole of the R\&D investment in Spain, both by businesses and by public research centers (see Table 3 ).

Since 1988, there has been a gradual tendency towards an increase in priorities of this kind in Spanish R\&D. There has undoubtedly been a modification of the system of public priorities, probably determined by the need to deal with the EC environmental norms urgently.

However, this recent progress cannot be used to ignore that the expenditure per capita which is budgeted for these purposes in Spain is clearly inferior to the same average spending in the EC. Although, in relative terms, in so far as Spain is concerned, the main imbalance is not as notable in ecological and social objectives but in the expenditure for technological/industrial objectives. 
Table 2: Gross Expenditure on Research and Development (GERD), European Community

\begin{tabular}{|c|c|c|c|c|c|c|c|}
\hline \multicolumn{8}{|c|}{ Million current PPP* (US\$) } \\
\hline & 1984 & 1985 & 1986 & 1987 & 1988 & 1989 & 1990 \\
\hline Belgium & $1,679.7$ & $1,788.7$ & $1,851.1$ & $1,956.9$ & $2,060.0$ & $2,167.8$ & $2,262.0$ \\
\hline Denmark & 715.2 & 785.3 & 879.0 & 971.5 & $1,075.9$ & $1,191.6$ & $1,297.4$ \\
\hline France & $13,627.7$ & $14,571.1$ & $15,146.6$ & $16,237.7$ & $17,511.6$ & $19,176.4$ & $21,129.4$ \\
\hline Germany & $18,589.5$ & $19,983.6$ & $21,224.9$ & $23,103.7$ & $24,578.3$ & $26,867.6$ & $28,688.3$ \\
\hline Greece & 176.3 & 201.7 & 205.6 & 222.0 & 251.7 & 275.1 & 300.7 \\
\hline Ireland & 177.8 & 202.9 & 223.6 & 252.0 & 269.0 & 299.6 & 332.5 \\
\hline Italy & $5,963.4$ & $7,014.5$ & $7,432.7$ & $8,277.8$ & $9,164.2$ & $10,360.0$ & $11,077.0$ \\
\hline Netherlands & $3,059.0$ & $3,437.3$ & $3,808.1$ & $4,148.3$ & $4,259.1$ & $4,626.5$ & $5,052.6$ \\
\hline Portugal & 202.4 & 226.0 & 254.4 & 285.2 & 319.8 & 358.5 & 401.9 \\
\hline Spain & $1,398.9$ & $1,629.3$ & $1,909.4$ & $2,164.6$ & $2,640.6$ & $3,174.1$ & $3,760.2$ \\
\hline UK & $13,417.2$ & $14,443.5$ & $15,548.3$ & $16,230.8$ & $17,042.4$ & $18,092.5$ & $19,207.2$ \\
\hline Total EC & $59,007.1$ & $64,284.9$ & $68,483.7$ & $73,850.5$ & $79,173.4$ & $86,589.7$ & $93,482.3$ \\
\hline \multicolumn{8}{|c|}{ Share of total EC GERD, in millions current PPP* (US\$) } \\
\hline & 1984 & 1985 & 1986 & 1987 & 1988 & 1989 & 1990 \\
\hline Belgium & 2.9 & 2.8 & 2.7 & 2.7 & 2.6 & 2.5 & 2.4 \\
\hline Denmark & 1.2 & 1.2 & 1.3 & 1.3 & 1.4 & 1.4 & 1.4 \\
\hline France & 23.1 & 22.7 & 22.1 & 22.0 & 22.1 & 22.2 & 22.6 \\
\hline Germany & 31.5 & 31.1 & 31.0 & 31.3 & 31.0 & 31.0 & 30.7 \\
\hline Greece & 0.3 & 0.3 & 0.3 & 0.3 & 0.3 & 0.3 & 0.3 \\
\hline Ireland & 0.3 & 0.3 & 0.3 & 0.3 & 0.3 & 0.4 & 0.4 \\
\hline Italy & 10.1 & 10.9 & 10.9 & 11.2 & 11.6 & 12.0 & 11.9 \\
\hline Netherlands & 5.2 & 5.4 & 5.6 & 5.6 & 5.4 & 5.3 & 5.4 \\
\hline Portugal & 0.3 & 0.4 & 0.4 & 0.4 & 0.4 & 0.4 & 0.4 \\
\hline Spain & 2.4 & 2.5 & 2.8 & 2.9 & 3.3 & 3.7 & 4.0 \\
\hline UK & 22.7 & 22.5 & 22.7 & 22.0 & 21.5 & 20.9 & 20.6 \\
\hline Total EC & 100.0 & 100.0 & 100.0 & 100.0 & 100.0 & 100.0 & 100.0 \\
\hline \multicolumn{8}{|c|}{ Per Capita Population, in current PPP* (US\$) } \\
\hline & 1984 & 1985 & 1986 & 1987 & 1988 & 1989 & \\
\hline Belgium & 170.4 & 181.6 & 187.7 & 198.3 & 208.5 & 218.1 & \\
\hline Denmark & 139.9 & 153.6 & 171.6 & 189.5 & 209.7 & 232.2 & \\
\hline France & 248.0 & 264.1 & 273.4 & 291.9 & 313.4 & 341.5 & \\
\hline Germany & 303.9 & 327.5 & 347.6 & 378.3 & 400.0 & 433.4 & \\
\hline Greece & 17.8 & 20.3 & 20.6 & 22.2 & 25.1 & 26.6 & \\
\hline Ireland & 50.4 & 57.3 & 63.1 & 71.1 & 76.3 & 85.2 & \\
\hline Italy & 104.7 & 122.8 & 129.9 & 144.4 & 159.5 & 180.1 & \\
\hline Netherlands & 212.1 & 237.2 & 261.3 & 282.9 & 288.6 & 311.6 & \\
\hline Portugal & 20.0 & 22.3 & 24.9 & 27.8 & 31.0 & 34.7 & \\
\hline Spain & 36.5 & 42.3 & 49.4 & 55.7 & 67.7 & 81.0 & \\
\hline UK & 237.5 & 255.1 & 273.9 & 285.1 & 298.6 & 316.3 & \\
\hline Total EC & 183.9 & 199.9 & 212.4 & 228.5 & 244.0 & 265.5 & \\
\hline
\end{tabular}

* PPP = Purchasing Power Parity

Source: OECD (1991:2); INE (1991) (Spain) 
Table 3: Gross domestic expenditure on R\&D by chapters of NABS in Spain (million of current pesetas)

\begin{tabular}{|c|c|c|c|c|c|c|c|c|}
\hline \multicolumn{9}{|c|}{ Government Sector } \\
\hline & 1982 & 1983 & 1984 & 1985 & 1986 & 1987 & 1988 & 1989 \\
\hline Total & $27,618.7$ & $30,749.5$ & $32,756.4$ & $37,558.9$ & $49,217.1$ & $58,187.6$ & $66,685.4$ & $77,137.0$ \\
\hline Agriculture & $5,031.5$ & $5,814.6$ & $7,452.3$ & $8,374.9$ & $9,722.7$ & $11,410.2$ & $14,877.0$ & $17,778.8$ \\
\hline Industry & $4,348.8$ & $4,460.8$ & $4,267.7$ & 174.5 & $1,159.9$ & 607.4 & $11,091.7$ & $12,572.8$ \\
\hline Defense & $2,948.7$ & $3,511.5$ & $3,387.6$ & $3,937.6$ & $2,847.8$ & $4,253.7$ & $7,591.6$ & $4,135.4$ \\
\hline Environment & 186.4 & 178.6 & 0.0 & 0.0 & 60.7 & 133.6 & $1,831.0$ & $4,608.3$ \\
\hline Health & 356.7 & 973.7 & $1,302.8$ & $1,296.3$ & $1,809.1$ & $5,121.7$ & $8,402.8$ & $10,398.3$ \\
\hline Social & 0.0 & & 69.3 & 31.7 & 242.1 & 271.7 & 124.7 & $1,911.1$ \\
\hline Others & $2,877.8$ & $1,698.5$ & $1,255.0$ & $6,578.5$ & $13,189.3$ & $13,372.2$ & $21,742.6$ & $25,732.3$ \\
\hline $\begin{array}{l}\text { Non } \\
\text { classified }\end{array}$ & $11,868.8$ & $14,111.8$ & $15,021.8$ & $17,165.5$ & $20,185.4$ & $23,017.1$ & $1,024.1$ & 0.0 \\
\hline \multicolumn{9}{|c|}{ Business Enterprise Sector } \\
\hline & 1982 & 1983 & 1984 & 1985 & 1986 & 1987 & 1988 & 1989 \\
\hline Total & $46,861.8$ & $52,142.9$ & $65,411.0$ & $85,795,2$ & $110,338.2$ & $126,706.6$ & $163,370.1$ & $191,153.2$ \\
\hline Agriculture & $6,999.9$ & 841.6 & $1,477.5$ & $1,875.8$ & $2,749.0$ & $4,721.0$ & $5,917.2$ & $5,651.8$ \\
\hline Industry & $29,828.6$ & $33,460.9$ & $33,045.8$ & $43,116.4$ & $60,667.3$ & $68,344.1$ & $89,285.9$ & $97,207.8$ \\
\hline Defense & $1,199.3$ & 945.6 & $6,609.3$ & $10,925.5$ & $12,865.3$ & $14,001.8$ & $15,998.3$ & $16,956.5$ \\
\hline Environment & 258.0 & 4.8 & 87.3 & 151,4 & 175.6 & 336.2 & 136.5 & 235.2 \\
\hline Health & $5,075.6$ & $4,482.7$ & $5,285.8$ & $6,218.5$ & $8,686.7$ & $10,641.1$ & $13,288.9$ & $16,273.2$ \\
\hline Social & 13.9 & 13.7 & 23.4 & 67.0 & 368.2 & 252.1 & 231.5 & 192.9 \\
\hline Others & $3,486.4$ & $12,393.6$ & $18,882.0$ & $23,440.6$ & $24,826.1$ & $28,410.3$ & $38,511.9$ & $54,635.8$ \\
\hline $\begin{array}{l}\text { Non } \\
\text { classified }\end{array}$ & 0.0 & 0.0 & 0.0 & 0.0 & 0.0 & 0.0 & 0.0 & 0.0 \\
\hline
\end{tabular}

Agriculture: Agricultural production and technology

Industry: Industrial production and technology

Defense: Defense

Environment: Control of environmental pollution

Health: Protection and improvement of human health

Social: Social Structure and relationships

Others: Other civil research

Data for Higher Education Sector not available

Source: Instituto Nacional de Estadística (INE), Spain

A comparative analysis of public budgetary credits which in 1989 were worth more than $60 \%$ of the total spending on R\&D in Spain, can give a good idea of the degree of priority and importance of the social and ecological concerns (see Table 4).

Thus, the R\&D boom in Spain occurred around 1988-1989, coinciding with a greater orientation towards ecological and social objectives in the same country.

Both in actual spending, as well as in budgetary measures, the Spanish situation seems to have improved, but there is still a major gap in the state's priorities. Within the small expenditure, the presence of ecological and social questions is verv small. in spite of the comparative growth of these priorities. In our opinion. 

Table 4: R\&D financing by chapters of NABS*, 1989, in ECU per head at 1989 values and exchange rates

\begin{tabular}{|c|c|c|c|c|c|c|c|c|c|c|c|c|}
\hline & \multirow[b]{2}{*}{ ESP } & \multirow[b]{2}{*}{ EC } & \multicolumn{4}{|c|}{ Large countries } & \multicolumn{6}{|c|}{ Medium and small countries } \\
\hline & & & FRG & FRA & UK & ITA & NL & BEL & DK & GRE & POR & IRE \\
\hline Total expenditures & 46.1 & 129.9 & 183.9 & 217.2 & 126.3 & 100.6 & 127.1 & 80.7 & 147.7 & 15.8 & 14.2 & 34.3 \\
\hline 3. Environment & 1.0 & 2.6 & 6.3 & 1.5 & 1.6 & 2.1 & 4.8 & 1.0 & 4.5 & 0.5 & 0.4 & 0.3 \\
\hline 4. Health & 3.0 & 5.1 & 6.3 & 7.2 & 6.4 & 4.7 & 3.3 & 2.1 & 2.6 & 1.3 & 0.6 & 1.4 \\
\hline 6. Agriculture & 2.6 & 4.8 & 3.8 & 8.6 & 5.6 & 2.7 & 5.7 & 4.7 & 11.4 & 2.6 & 2.5 & 6.7 \\
\hline 7. Industry & 7.8 & 17.7 & 23.5 & 28.2 & 10.7 & 17.8 & 28.7 & 15.4 & 23.0 & 1.9 & 2.5 & 11.4 \\
\hline 8. Social & 0.6 & 2.5 & 4.5 & 1.0 & 2.7 & 3.6 & 2.6 & 0.5 & 7.0 & 0.7 & 0.2 & 2.9 \\
\hline 10. GUF & 7.5 & 30.3 & 60.3 & 24.1 & 22.9 & 33.0 & 44.3 & 18.6 & 52.3 & 6.1 & 5.2 & 8.9 \\
\hline 11. Non-oriented & 4.8 & 15.8 & 25.6 & 32.9 & 6.0 & 10.7 & 14.2 & 18.9 & 32.9 & 0.6 & 0.3 & 0.7 \\
\hline 13. Defense & 9.7 & 31.5 & 23.5 & 83.6 & 57.1 & 6.8 & 4.1 & 0.5 & 0.6 & 0.3 & 0.0 & 0.0 \\
\hline
\end{tabular}

* NABS Objectives:

1. Exploration and exploitation of the earth

2. Infrastructure and general planning of land-use

3. Control of environmental pollution

4. Protection and improvement of human health

5. Production, distribution and rational use of energy

6. Agricultural production and technology

7. Industrial production and technology

8. Social structure and relationships

9. Exploration and exploitation of space

10. Research financed from general university funds (GUF)

11. Non-oriented research

12. Other civil research

13. Defense

Source: Eurostat 
this change is due to the growing mid- and long-term influences of the European Community.

The late inclusion of ecological and social objectives in R\&D activities can be explained by a poor social awareness and the absence of these questions on the political agenda. On the other hand, it is significant that Spanish environmental groups are not represented in Parliament or in local government.

A determining factor in the formation of public policies on science and technology, and in particular for the importance of social and ecological concerns within these policies, is the degree of urgency and importance given to these concerns by Spanish opinion.

Public opinion polls have helped to establish differences in values between countries fo the European Community. When the so-called welfare indicators ${ }^{7}$ of EC countries are examined, it can be seen that, while in Spain only one out of four citizens considered that the state of the environment was an indicator of well-being, the EC average was one-in-three. Awareness of environmental issues was, indeed, very high in Luxembourg, Denmark, Italy, the Netherlands and Germany. Below the EC average, at around one-in-five, were France and the United Kingdom; and further behind still, Portugal and Greece (CEC 1986).

It is for these reasons, namely that Spaniards have a low perception of environmental problems and that there is a near absence of any organization of social interests, that it has been maintained that the Environmental Program for Industry and Technology (PITMA) is better designed for the "diffusion" of environmental policies than private initiatives. The former system has arisen as a result of EC norms, and the latter tend to arise in countries with a higher level of development, especially those with highly organized pressure or interest groups.

Another significant point about the political importance or environmental problems is that until 1991, the administrative responsibility for these matters in central government was held by a General Secretariat for the Environment (at the third level of government, after ministers and secretaries of state). It was not until the ministerial modifications of 1991 that political responsibility was taken to a higher level, with the establishment of the Secretary of State for Environmental Policy and Water.

In any case, public $R \& D$ initiatives with social and ecological approaches are few and evidently uncoordinated, and they are at present dispersed among various ministerial departments.

\section{Conclusion. Convergence with Europe: How Far are We?}

A surface reading of the indicators of science and technology in use in Spain, together with their recent evolution, could give us a optimistic view of the Spanish situation. However. a comparative analysis of the variation between the percentage 
of the GDP invested in R\&D and the per capita income, expressed logarithmically, show that Spain is at the top of the group of Europe's least developed countries, with Ireland, Greece and Portugal (Quintanilla 1992). Logarithmic representation shows, in addition, that there is an area - between 1 and $1.5 \%$ of the GDP spent on R\&D - beneath which any increase in expenditure on science and technology generates results of virtually no significance.

The influence of $R \& D$ in relation to economic development can be described in a metaphor involving a passenger on a conveyor belt. If the passenger advances in the same direction as the conveyor belt, his speed gains substantially. If he does not move, his speed will remain identical to that of the conveyor belt. The image of the passenger and the conveyor belt suggests the relation between investment in R\&D and economic development: overcoming the area of difficulty (expressed in the logarithm) is indispensable if $R \& D$ is to acquire any social significance.

In these circumstances, it can hardly be surprising that technology policy and its partner, science policy, in Spain, have been of little historical relevance, suffering from a lack of strategy and an appropriate model. Some actions and mechanisms put forward in recent years have managed to generate resources and initiatives, but at the same time, they have exposed basic structural deficiencies and have been useful in the elaboration of an early evaluation of that which has been achieved and of the problems still to be confronted. Among these, for obvious reasons of time and lack of experience, it is evident that the biggest problems are the social construction of technological development and the social compatibility of technical change.

To conclude and summarize, the improvement in social and ecological terms of science and technology policies in Spain is characterized by certain facts and circumstances which would explain the situation of Spanish underdevelopment in relation to the rest of the European Community. The perception and concern of public opinion for environmental problems in Spain is very low. There is an important gap, in terms of the level of economic and scientific/technological development, between Spain and the EC average.

This low perception of social and ecological problems, in conjunction with the institutional weakness and the absence of strong interest groups in democratic civil society, have ensured that environmental issues find their way to the political agenda via two streams of access: international diffusion of approaches, and the personal leadership of particular politicians.

In any case, we must remind ourselves that the introduction of items or issues on the Spanish political agenda, in the fields of science and technology in recent years, have been aimed towards the mobilization and increase of the practice and resources of $\mathrm{R} \& \mathrm{D}$, and not by discriminating or well-chosen concerns. 
Notes

[1] The text entitled The Industrial Policy of the New Spain, published in 1942 by the Ministry of Industry, quoted the head of state saying that there was a need to "increase production". The industrial policy was founded on this idea.

[2] It must be pointed out that the creation of the CSIC occurred at the same time as that of the Centre National de la Recherche Scientifique (CNRS) in France. Both institutions appeared in 1939, although in circumstances which were radically opposed in historical and sociological terms. The French organism was the reflection of a popular government, upon which a rapid conflagration was looming, while the CSIC appeared at the end of a civil struggle, and with an entirely different ideological framework to its counterpart, as well as a different orientation in its aims and objectives. The CNRS was preparing to develop aspects of technology and experimentation, and the CSIC was to begin a kind of crusade (it was said that among the essential functions of the institution, that it must "put scientific production at the service of the spiritual and material interest of the nation").

[3] The OECD (1971) points out that the 2nd Development Plan required more than 41,000 million pesetas investments, although few more than 6,000 million were conceded.

[4] Several studies of the years 1967-1974 pointed to this situation. This was the actual period in which the development plans operated. For example, the CSIC (1977) carried out one of the few studies in existence on the matter from which the following conclusions can be drawn:

In 1974 there was, finally, a substantial increase in spending on R\&D by businesses ( $145 \%$ in fixed pesetas), which indicates a positive response of the concerted plans.

Most spending was very concentrated in sectorial terms (the chemical industry, the pharmaceutical industry, transport materials, and electrical and electronic goods). The proportion of $R \& D$ expenditure with respect to the added value of each sector or branch was very varied, from a minimum of $0.0077 \%$ for agriculture, forestry, sheep, pig and cattle farming, and fishing, to a maximum of $1.98 \%$ for the chemical industry, pharmaceuticals, and oil and petroleum products).

Spending came almost entirely from the businesses themselves, with no significant funding from loans or grants from the mentioned concerted plans which the public administration had been supposedly conceding.

Capital spending was relatively low, which indicates a structural weakness in businesses in relation to $R \& D$.

The distribution of spending was split thus: $2.4 \%$ in basic research, $30.7 \%$ in applied research, and $66.9 \%$ in technological development.

Businesses of a critical size (say those with more than 250 employees) constituted $60 \%$ of those businesses involved in R\&D and their spending constituted $91 \%$ of the sector's total expenditure.

In any case, the size of R\&D units was small; $82 \%$ of companies, in spite of their activity in the promotion and management of $R \& D$, employed less than ten scientists and engineers to carry out these tasks.

[5] We must remember that General Franco died in 1975. The first democratic General Elections took place on the 15th of June of 1977. The new Constitution was approved in December 1978. In 1979 there were new elections. In October of 1982, the Socialist party won its first victory. 
[6] For example, the relation between payments for technology bought abroad and domestic expenditure on R\&D has always been significant: the United States invested 200 times more on technological development than it bought, France and Germany five times, and Italy 1.3 times, while in Spain the business sector invested half of what it spent abroad on technology in R\&D.

[7] The system consists in indicating the percentage of interviewees in each one of the countries which pointed out that the question was an indicator of well-being.

\section{References}

Buesa, M., J. Molero (1989) Innovación industrial y dependencia tecnológica en España, Madrid: EUDEMA.

Bush, V. (1945) Science, The Endless Frontier: A Report to the President on a Program for Postwar Scientific Research, Washington, DC: Government Printing Office.

Carreras, A. (1987) La industria: atraso y modernización, in: J. Nadal, A Carreras, C. Sudria (eds.) La economía española en el siglo XX. Una perspectiva histórica, Barcelona: Ariel, 280-312.

CEC (Commission of the European Community) (1986) Eurobarometer, 1986: Los europeos y el medio ambiente, Brussels: CEC.

Chandler, A.D. (1962) Strategy and Structure, Cambridge, MA, London: MIT.

Chandler, A.D. (1977) The Visible Hand. The Managerial Revolution in American Business, Cambridge, MA, London: The Belknap Press of Harvard University Press.

CICYT (1988) Plan Nacional de Investigación Científica y Desarrollo Tecnológico, Madrid: Ministerio de Educación y Ciencia.

CICYT (1991) Memoria de desarrollo del Plan Nacional de I+D in el período 1988-1990, Madrid: Comisión Interministerial de Ciencia y Tecnología.

Crespo, A., M. Costa, M. Millán (1991) Política de I+D en materia medioambiental: perspectiva científica, in: R. Dorado, J. Rojo, E. Triana, F. Martinez (eds.) Ciencia, tecnología e industria en España, Madrid: Fundesco, 239-260.

CSIC (1977) La investigación científica y el desarrollo tecnológico in España, 1967-1974. Evolución y comparación con algunos países europeos, Madrid: Gabinete Técnico del CSIC.

De Andrés, C. (1991) Tecnologías industriales medioambientales, in: R. Dorado, J. Rojo, E. Triana, F. Martinez (eds.) Ciencia, tecnologia e industria en España, Madrid: Fundesco, 261-277.

Dosi, G.(1988) Sources, Procedures and Microeconomics Effects of Innovation, in: Journal of Economic Literature September (XXVI): 1120-1171.

Dosi, G. (1991) Perspectives on Evolutionary Theory, in: Science and Public Policy 6 (18): 353-361.

Espina, A. (1992) Recursos humanos y politica industrial, Madrid: Fundesco.

Eurostat (1991) Estadística de financiación de la $I+D$, Luxemburg: Eurostat.

Fagerberg, J. (1987) A Technology Gap Approach to Why Growth Rates Differ, in: Research Policy (16): 87-99.

García-Delgado, J.L. (1987) La industrialización y el desarrollo económico de España durante el franquismo, in: J. Nadal, A. Carreras, C. Sudria (eds.) La economía española in el siglo XX. Una perspectiva histórica, Barcelona: Ariel, 164-189. 
García-Delgado, J.L. (ed.) (1990) La Economía Española en la Transición y la Democracia (1973-1986), Madrid: Centro de Investigaciones Sociológicas.

Gerelli, E. (ed.) (1982) La politica per l'innovazione industriale: problemi e proposte, Milan: Angeli.

Gerelli, E. (1983) Per una politica dell'innovazione industriale, Milan: Angeli.

INE (various years) Estatística sobre las actividades en investigación cientifica y desarollo tecnológico, Madrid: INE.

Lafuente, A., L. Oro (1991) Evolución del sistema de ciencia y tecnologia en España. El Plan Nacional de I+D, in: R. Dorado, J. Rojo, E. Triana, F. Martinez (eds.) Ciencia, tecnología e industria en España, Madrid: Fundesco, 33-123.

Lora Tamayo, M. (1990) Recuerdos del Consejo Superior de Investigaciones Científicas en su 50 Aniversario, in: Arbor 529: 99-115.

Martín, C. (1990) Espagne, in: P. Buigues, F. Ilkovitz, J.F. Lebrun (eds.) L'impact sectoriel du marché intérieur sur l'industrie: les enjeux pour les Etats membres, Brussels: CEC, 221-233

Martín, C., L. Rodriguez (1985) Política de promoción del Cambio Técnico y Reindustrialización, mimeo D.T.8502, Madrid: Fundación Empresa Pública.

Martín-Aceña, P., F. Comín (1992) El Estado en la industrialización española de posguerra: el Instituto Nacional de Industria, in: L. Prados de la Escosura, V. Zamagni (eds.) El desarrollo económico en la Europa del Sur: España e Italia in Perspectiva histórica, Madrid: Alianza Universidad, 421-461

Ministerio de Industria y Energía (1990) España en Europa un futuro industrial (La politica industrial en el horizonte 1992), Madrid: Ministerio de Industria y Energia.

Mowery, D., N. Rosenberg (1989) Technology and the Pursuit of Economic Growth, Cambridge, GB: Cambridge University Press.

Muñoz, E. (1982) Política científica, innovación y empleo, in: A. Nieto, J.M. Gómez Fatou, E. Muñoz, J.A. Muñoz-Delgado, T. Mendizabal, C. Llaguno, F. Catalina (eds.) Apuntes para una política científica. Dos años de investigación in el CSIC: 1980-1982, Madrid: Consejo Superior de Investigaciones Científicas, 219-226.

Muñoz, E. (1990) El CSIC, una síntesis de tradición y futuro. Media centuria in la balanza de la ciencia española, in: Arbor 529: 13-28.

Muñoz, E., F. Ornia (1986) Ciencia y Tecnología una oportunidad para España, Madrid: Ministerio de Educación y Ciencia-Aguilar.

Myro, R. (1981) La estrategia de la Empresa Pública concurrencial en España: un análisis de la actuación del Instituto Nacional de Industria, in: Investigaciones Económicas 15: 23-50.

Nelson, R., S. Winter (1977) In Search of a Useful Theory of Innovation, in: Research Policy 1 (6): 36-76.

Nelson, R., S. Winter (1982) An Evolutionary Theory of Economic Change, Cambridge, MA, London: The Belknap Press of Harvard University Press.

Nelson, R., S. Winter, H.L. Schütte (1976) Technical Change in an Evolutionary Model, in: Quarterly Journal of Economics 1 (XC): 90-118.

Nieto, A. (1982) La investigación científica en España, in: A. Nieto, J.M. Gómez Fatou, E. Muñoz, J.A. Muñoz-Delgado, T. Mendizabal, C. Llaguno, F. Catalina (eds.) Apuntes para una política científica. Dos años de investigación en el CSIC: 1980-1982, Madrid: Consejo Superior de Investigaciones Científicas, 203-205. 
Nieto, A. (1990) El CSIC durante el periodo de la consolidación democrática in: Arbor 529: $29-48$.

Noble, D.F. (1977) America by Design, Oxford, New York: Oxford University Press.

OECD (various years) Science and Technology Indicators, Paris: OECD.

OECD (1971) Políticas nacionales de la Ciencia: España, Madrid: Ministerio de Educación y Ciencia.

Pavitt, K. (1979) Technical Innovation and Industrial Development. 1. The New Causality, in: Futures 6 (11): 458-470.

Pavitt, K. (1980) Technical Innovation and Industrial Development. 2. The Dangers of Divergence, in: Futures 1 (12): 35-44.

Pavitt, K. (1984) Sectoral Patterns of Technical Change: Towards a Taxonomy and Theory, in: Research Policy (13): 343-373

Quintanilla, M.A. (1992) El Sistema español de ciencia y tecnología. (Proyecto EPOC), in: Arbor 554-555: 9-251.

Rojo, J.M. (1991) El sistema de I+D: fortalezas y debilidades, in: R. Dorado, J. Rojo, E. Triana, F. Martinez (eds.) Ciencia, tecnología e industria en España, Madrid: Fundesco, 15-32.

Ronayne, J. (1984) Science in Government, Caulfield East, Baltimore: Edward Arnold.

Ros-Hombravella, J. (1973) Capitalismo español: De la Autarquía a la estabilización (1939-1959), Madrid: Cuadernos para el Diálogo.

Rosenberg, N. (1991) Critical Issues in Science Policy Research, in: Science and Public Policy 6 (18): 335-346.

Saez, F. (1991) Tecnología y empleo en España, Madrid: Instituto de Estudios y Análisis Económicos.

Salter, W.E.G. (1960) Productivity and Technical Change, Cambridge, GB: Cambridge University Press.

Sanchez, P. (1984) La dependencia tecnológica española, Madrid: Ministerio de Economía y Hacienda.

Sanz, L., C.E. García (1990) Presente y perspectivas de la brecha tecnológica en la Comunidad Europea, in: M. Gamella, M. Hernandez (eds.) Nuevas Tecnologías y Orden Económico Internacional, Madrid: Fundesco, 17-48.

Sanz, L., J. Pfretzschner (1992) Política científica y gestión de la investigación: El CSIC (1986-1990) en el sistema español de ciencia y tecnología, in: Arbor 557: 9-51.

Schumpeter, J.E. (1939) Business Cycles, New York, London: Mac Graw-Hill.

Segura, J. (1983) Crisis y estrategias alternativas: el caso española, in: Pensamiento Iberiamericano 3: 93-112.

Soete, L.L.G. (1981) A General Test of Technological Gap Trade Theory, in: Weltwirtschaftliches Archiv 4 (117): 638-660. 